\title{
Another Story: What Public Opinion Data Tell Us About Refugee and Humanitarian Policy
}

Brad Blitz

Middlesex University and London School of Economics

\section{Executive Summary}

The global reaction to US President Donald Trump's executive order, "Protecting the Nation from Foreign Terrorist Entry into the United States" of January 27, 2017, ${ }^{1}$ revealed great public sympathy for the fate of refugees and the principle of refugee protection. In the case of Europe, such sympathy has, however, been dismissed by politicians who have read concerns regarding security and integration as reason for introducing restrictive policies on asylum and humanitarian assistance. These policies are at odds with public sentiment. Drawing upon public opinion surveys conducted by Amnesty International, the European Social Survey (ESS), and Pew Global Attitudes Survey across the European Union and neighboring states, this article records a marked divide between public attitudes towards the treatment of refugees and asylum seekers and official policies regarding asylum and humanitarian assistance, and seeks to understand why this is the case.

The article suggests that post-9/11 there has been a reconfiguration of refugee policy and a reconnecting of humanitarian and security interests which has enabled a discourse antithetical to the universal right to asylum. It offers five possible explanations for this trend: i) fears over cultural antagonism in host countries; ii) the conflation of refugees and immigrants, both those deemed economically advantageous as well as those labelled as "illegal"; iii) dominance of human capital thinking; iv) foreign policy justification; and v) the normalization of border controls. The main conclusion is that in a post-post-Cold War era characterized in part by the reconnecting of security and humanitarian policy, European governments have developed restrictive policies despite public sympathy. Support for the admission of refugees is not, however, unqualified, and most states and European populations prefer skilled populations that can be easily assimilated. In order to achieve greater protection and more open policies, this article recommends human rights actors work with the United Nations High Commissioner for Refugees (UNHCR) and its partners to challenge the above discourse through media campaigns and grassroots messaging.

1 Protecting the Nation from Foreign Terrorist Entry into the United States, Exec. Order No. 13769, 82 Fed. Reg. 8977 (Jan. 27, 2017).

(C) 2017 by the Center for Migration Studies of New York. All rights reserved. 
Further recommendations include:

- Challenging efforts to normalize and drawing attention to the extreme and unprecedented activities of illegal and inhumane practices, e.g., detention, offshore processing, and the separation of families through the courts as part of a coordinated information campaign to present a counter moral argument.

- Identifying how restrictive asylum policies fail to advance foreign policy interests and are contrary to international law.

- Evidencing persecution by sharing information with the press and government agencies on the nature of claims by those currently considered ineligible for refugee protection as part of a wider campaign of information and inclusion.

- Engaging with minority, and in particular Muslim, communities to redress public concerns regarding the possibility of cultural integration in the host country.

- Clarifying the rights of refugees and migrants in line with the UNHCR and International Organization for Migration (IOM) guidelines and European and national law in order to hold governments to account and to ensure that all - irrespective of their skills, status, nationality or religion - are given the opportunity to seek asylum.

- Identifying and promoting leadership among states and regional bodies to advance the rights of refugees.

\section{Introduction}

The global reaction to US President Donald Trump's executive order, "Protecting the Nation from Foreign Terrorist Entry into the United States" of January 27, 2017, ${ }^{2}$ revealed great public sympathy to the fate of refugees and the principle of refugee protection more generally. Demonstrations in the United States were accompanied by European protests and demands that the UK Prime Minister Theresa May explicitly condemn the "Muslim ban" (House of Commons 2017a). These protests were also accompanied by acts of hospitality where both British and other Europeans opened up their homes to those affected by the ban who were caught in transit. Such expressions of solidarity were not new. Throughout the "refugee crisis" of 2015-2016, large sections of European society showed their support for a more humane and effective response from their governments through charitable acts and public outcry. In addition to solidarity campaigns and direct assistance to migrants arriving onto European soil, public opinion was occasionally reflected in successful advocacy efforts. For example, following much pressure from Calais Solidarity groups, the $2016 \mathrm{UK}$ Immigration Act was amended further to the "Dubs amendment" which called upon the UK government to relocate unaccompanied children from European countries.

2 Id.

3 Immigration Act 2016, c. 19, § 67 (Eng.). 
During this period, in spite of public support, European governments introduced many restrictions to curb arrivals in the name of both border management and the preservation of national sovereignty. Most notably, in February 2017, the UK government cancelled the Dubs relocation scheme which was to be capped at just 350 unaccompanied children admitted to the UK (House of Commons 2017b).

This article reviews the development of European asylum and humanitarian policy and the public response to growing restrictions against the right to asylum. Drawing upon public opinion surveys conducted across the European Union and neighboring states on either side of the peak of the 2015 refugee crisis - the Amnesty International Refugees Welcome Index (Amnesty 2016), the European Social Survey (ESS 2016), and the Pew Global Attitudes Survey (Pew 2016) - this article argues that there has been a marked divide between public attitudes towards the treatment of refugees and asylum seekers and official policies regarding asylum and humanitarian assistance. This article seeks to explain the reasons for the above discord.

The first part of the article provides a brief review of the historical context for the development of contemporary national and EU policies on asylum management and humanitarian assistance. Noting how Cold War security interests eventually became decoupled from humanitarian policy in the 1990s, this article describes how security interests were reinserted in the formulation of humanitarian policy during the past decade. The second part then presents public opinion data from multiple sources to reveal a noticeable discord between sections of the European public and their political leaders. Drawing upon data collected on either side of the peak in the refugee "crisis," that is, before and after April 2015, this article assesses their reliability as evidence of European sympathy for more open refugee and asylum policies before offering some explanations for the divide between recorded public opinion and the direction of national policies on asylum and humanitarian assistance.

The central argument of this paper is that, following $9 / 11$, there has been a reconfiguration of refugee policy and a reconnecting of humanitarian and security interests which has enabled a discourse antithetical to the universal right to asylum. It offers five possible explanations for this shift: 1) refugees are often perceived and treated as immigrants, irrespective of their claims of persecution; 2) Western states have expressed vocal fears that refugees may not integrate but rather antagonize cultural sensitivities in host countries; 3) the refugee regime is being undermined by a shift towards a human capital logic which favors skilled individuals; 4) the control on asylum is informed by foreign policy justifications; and 5) the use of border controls and prevalence of border management discourse is undermining concerns regarding protection. The main conclusion of this paper is that in a post-postCold War era characterized in part by the reconnecting of security and humanitarian policy, European governments have developed restrictive policies in spite of widespread public sympathy for refugees and asylum seekers. Furthermore, refugee-receiving states have expressed clear preferences and favor certain groups over others. The data record that, irrespective of their need for protection, most states and European populations prefer to admit skilled populations that can be easily assimilated. Such preferences risk undermining the nondiscrimination principle that is central to refugee protection. 


\section{Historical Developments and the Current Refugee Crisis}

The design of humanitarian and asylum policies during the twentieth and early twenty-first century replicated major geopolitical trends. During the Cold War especially, humanitarian policy was a visible offshoot of overseas development and foreign policies which reflected wider security concerns. This was clearly expressed in the Truman Doctrine of 1947. The then president of the largest donor state to the United Nations declared that:

"[I]t must be the policy of the United States to support free peoples who are resisting attempted subjugation by armed minorities or by outside pressures . . . to work out their own destinies in their own way. I believe that our help should be through economic and financial aid which is essential to economic stability and orderly political processes."

(Truman 1947)

Following the expansion of the Marshall Plan to western and southeastern Europe, in addition to the placement of troops and weaponry, superpower rivalry between the United States and the then Soviet Union was expressed through their distribution of foreign assistance to weak and frontline states, above all, in the Middle East and Africa.

In addition, the Cold War brought a utilitarian logic to the idea of refugee protection. In spite of the rights focus heralded by the 1951 Convention relating to the Status of Refugees ("the Refugee Convention") and expanding UN system, throughout the Cold War, certain nationalities were privileged in the design of both immigration and refugee policy, most notably more than one million Cubans who enjoyed preferential treatment by the United States (Bon Tempo 2008; Garcia 1996; Zucker and Zucker 1995). Unlike other nationalities, as a result of domestic political pressure and geopolitical alignments, Cubans were granted access to refugee resettlement in the United States and exempted from immigration quotas as a result of the 1966 Cuban Adjustment $\mathrm{Act}^{4}$ and the Immigration and Nationality Act Amendments of $1976 .{ }^{5}$ Such treatment stood in marked contrast to the fate of Haitians seeking to enter the United States and who were also fleeing political oppression, raising charges of racism at the heart of US refugee policy (Loescher and Scanlan 1986; Zucker and Zucker 1995).

While US immigration and refugee policies saw some revision during the later years of the Cold War, in particular with the "wet foot, dry foot" policy that curtailed Cuban settlement in the United States to those who managed to reach the shore, not simply territorial waters as in the past (Bon Tempo 2008; Loescher and Scanlan 1986), the logic of the Truman Doctrine remained intact for more than four decades. During this time, with the exception of some small flows of largely political refugees from Hungary, Chile, and Argentina, and others fleeing Communist regimes, refugee flows were regionally contained as a result of the political divisions which reinforced Atlantic and Soviet claims of competing and distinct spheres of influence. Palestinians, the most controversial face of refugees in the Cold War, were treated as a special category within the UN system, placed under the management of

4 Cuban Adjustment Act, Pub. L. No. 89-732, 80 Stat. 1161 (1966).

5 Immigration and Nationality Act, Pub. L. No. 89-236, 79 Stat. 911 (1968), amended by Pub. L. No. 94-571, 90 Stat. 2703 (1976). 
the UN Relief and Works Agency for Palestine Refugees in the Near East (UNRWA), an agency that operated without a specific charter or statute (Bocco 2009). Exempt from the Refugee Convention, Palestinian refugees were confined to camps in neighboring states where they were denied the prospect of integration, as well as many civil and political rights afforded to nationals in those host states (Takkenberg 2000).

With the collapse of the Soviet Union, and the emergence of an enlarged European Union as a global actor, the premise of using overseas development aid shifted, as did longstanding approaches to foreign policy making. Further to much advocacy by refugee rights groups, by the mid-1990s, the above Cold War practices were revised (Newland 1995). In particular, following the conflicts in the former Yugoslavia, aid was now seen as a means of complementing diplomatic pressure, rather than as direct extension of security policy. This in turn helped to forge a divide between security policy, still characterized by Western engagement with an expanding North American Treaty Organization (NATO), and foreign policy which was broadened to include a range of interventions including development and humanitarian assistance that introduced greater emphasis on rights. Humanitarian policy subsequently reflected changes in the new geopolitical order and key principles of the Truman Doctrine, with the longstanding tenets of conditionality and containment that had defined the previous four decades downgraded.

Though states still sought to use foreign assistance selectively to pursue agendas for interventionism, policy making was altogether more fluid and aid policies illustrated a growing preference for multilateralism, with the European Union, UNHCR, and World Bank playing a more prominent role especially in post-conflict assistance (Scott and Bannon 2003). The statist logic of Cold War humanitarian assistance and development planning also gave way to a greater emphasis on privatization and local decision-making which reflected new preferences and the effect of globalization on foreign affairs (Duffield 2001) - a trend which continues to attract criticism (Provost 2016). Joanna Macrae describes the refocusing of humanitarian policy as the move towards a "coherence agenda" where the concept of sovereignty was enlarged and aid seen as a central tool of conflict resolution, even if domestic and international interests appeared to diverge (Macrae and Leader 2000; Macrae, Brusset, and Tiberghien 2002). During this period aid was directly contracted to NGOs and there was greater donor coordination and an emphasis on targets (Duffield 2001), as aid agencies established an increased operational presence in previously neglected, inaccessible, or nonpriority regions in Asia, Africa, and southeastern Europe.

The refocusing of humanitarian policy could also be seen in academic and political discourse which called attention to participatory and non-statist approaches to development. Western governments also began rethinking the purpose of aid. Commenting on this trend in the context of US development policy, Joseph Nye (1999) argued that the normative tendency reflected a broader understanding of the national interest - moral values were simply "intangible interests," he maintained. Following the wars in Croatia, Bosnia, and genocide and ethnic conflict in Rwanda and the Great Lakes region of Africa, the United Kingdom set out a plan for an "ethical foreign policy" and shifted from bilateral loans preferring instead grants and collaboration through the EU and UN systems (The Guardian 1997).

The European Union's foreign policies were described in the language of cooperation with third countries. Although refugee policy was not immediately affected, following the 1999 
Amsterdam Treaty ${ }^{6}$ and the conclusions of the 1999 Tampere European Council, irregular migration was refashioned along the lines of a "comprehensive approach" which later blended with key aspects of refugee protection (European Parliament 1999). The aim of this approach was to address both human rights and development issues in third countries, and in that way, provide greater consistency between the internal and external policies of the European Union. Although there was a strong development focus, central to the European Union's ambitions were the management of irregular migration flows and the introduction of sanctions against the traffickers of "illegal immigrants." Development concerns were channelled through different policy instruments, including regional agreements such as the 2000 Africa, the Caribbean, and the Pacific (ACP)-EU Partnership Agreement ${ }^{7}$ and Economic Partnership Agreements between the European Union and Africa, the Caribbean, and the Pacific, which apply to both individual states (Cote d'Ivoire, Ghana, Papua New Guinea, Fiji), regional groupings (eastern and southern Africa, the East African Community, the Caribbean), and inter-regional organizations (e.g., the Economic Community of West African States [ECOWAS] and the Southern African Development Community [SADC]) (European Commission 2014).

After the terrorist attacks of September 11, 2001 in New York, Pennsylvania, and the Pentagon, the focus on refugee policy shifted both as a result of increased securitization and further expansion of the European Union's political dimension. This was accompanied by technological developments, including the sharing of information between EU member states and the United States, and the creation of "smart borders." While most evident in the United States where a shift in policy led to the suspension of visas, EU states had previously agreed lists of countries and a well-established system of visa controls which similarly targeted certain nationals. These were complemented by an extensive range of return measures. Specifically, the linking of internal and external policies, which reflected the greater focus on security as noted at the 2002 Seville European Council meeting, was to be achieved by means of readmission agreements. In this way, the European Union expanded both its policy with respect to third countries and also shored up its own internal policies. These agreements require third countries to readmit their own nationals who do not have the right to remain on EU territory (European Union 2002). ${ }^{8}$

The use of readmission to deter long stays was laid down in the Global Approach to Migration and Mobility, ${ }^{9}$ first proposed for Africa and the Mediterranean in late 2005 and later extended to southern Europe, including the Balkans, and the former Soviet bloc in 2006. The policy was again revamped in 2011 as mobility partnerships, bilateral country agreements to share the responsibility and management of circular migration. ${ }^{10}$ These

6 Treaty of Amsterdam amending the Treaty on European Union, the Treaties establishing the European Communities and certain related Acts, Oct. 2, 1997, 1997 O.J. (C 340) 1.

7 Cotonou Agreement, June 23, 2000, 2000 O.J. (L 317) (revised June 25, 2005 and June 22, 2010).

8 Since 1999, the European Union has concluded readmission agreements with: Hong Kong (2004), Macao (2004), Sri Lanka (2005), Albania (2006), Russia (2007), Ukraine (2008), Macedonia (2008), Bosnia and Herzegovina (2008), Montenegro (2008), Serbia (2008), Moldova (2008), Pakistan (2010), Georgia (2011), Armenia (2014), Azerbaijan (2014), Turkey (2014), Cape Verde (2014), and Turkey (2016).

9 Communication from the Commission to the European Parliament, the Council, the European economic and Social Committee and the Committee of the Regions - The Global Approach to Migration and Mobility, COM (2011) 743 final (Nov. 18, 2011).

10 Id. 
mobility partnerships had no basis in law but were increasingly seen as the European Union's preferred policy tool for handling irregular migration across the European Union's areas of interest. ${ }^{11}$ Others have described these partnerships as an expression of the European Union's "extra-territorialisation," since they function as a means of immigration control beyond the national borders of EU member states (Carrera and Sagrera 2009). Most important, the Global Approach to Migration and Mobility and the European Union's preference for mobility partnerships would inform the eventual design of the EU-Turkey deal of 2016 that sought not only to control irregular migration but also refugee flows to the European Union (Council of the European Union 2016).

In spite of the attempt to coordinate the European Union's external relations with third countries, immigration and refugee policy remained matters of national control, and within less than 10 years, visible cracks appeared in both foreign policy cooperation and the regional frameworks the European institutions had tried to put in place. Divisions among EU member states over the war in Iraq and following the failed interventions in Iraq and Afghanistan, were further polarized by the Syrian crisis which saw over 11 million people displaced and an estimated 13.5 million people in need of humanitarian assistance (European Commission 2017). Although the European Union and its member states have provided more than $€ 9.2$ billion to support relief inside Syria, as well as $€ 445$ million in relief allocated in 2016 (European Commission 2017), the handling of the "refugee crisis" has exposed sizeable rifts in the post-Cold War compact regarding the purpose of humanitarian assistance and the nature of refugee protection.

While European policy was defined by declarations of shared policy areas, for example, the relocation plan for some 160,000 refugees following the EU-Turkey deal in 2016 and the use of mobility partnerships, as well as by the growing restrictions on legal pathways to asylum, it also had to contend with asymmetric responses from EU member states. Some EU members, such as the United Kingdom, balanced the use of aid against the expense of granting asylum to large numbers of Syrian refugees and refused to participate in the relocation effort. Other states, above all the Visegrad countries of the Czech Republic, Hungary, Slovakia, and Poland, largely refused to admit refugees altogether in spite of shared policy positions. Their refusal to cooperate with EU policy was based on cultural grounds - Muslim refugees could not be integrated into their predominantly Christian countries (Keating 2015). Rather, Muslim refugees represented the "Trojan horse of terrorism," claimed Hungarian Prime Minister Viktor Orban (Brunsden 2017). Most EU members closed their borders, often using razor wire fences and other repressive approaches to deter refugees seeking protection. Following terror incidents in Paris, Brussels, Cologne, and Nice, such actions were justified on the grounds that refugees from the Middle East in particular might pose a potential terror threat.

The prevailing logic of multilateralism set out in the 1990s, in particular working through actors such as the UNHCR and EU agencies, has also been challenged by competing narratives about the ways in which national humanitarian policies should be conducted, which is often in antagonism to the above partner institutions. The UNHCR has been especially critical of EU policy (Spindler and Clayton 2016), and NGOs, above all Médecins Sans

11 Mobility agreements have been signed with Cape Verde (2008) and later, Armenia (2011), Azerbaijan (2014), Georgia (2008), Jordan (2014), Moldova (2013), Morocco (2013) and Tunisia (2014). 
Frontières (2016), have been even more outspoken. These organizations have contested the design of the EU-Turkey deal which introduces the prospect of returning refused asylum seekers from the European Union to Turkey, as well as the practice of holding refugees in closed detention centers on the Greek islands. The division between implementing partners and the agendas of national governments illustrates a divided trend in the management of humanitarian policy.

In addition, we note a diverging pattern where, in addition to criticism by humanitarian actors, civic groups have been mobilized in opposition to harsh refugee and asylum policies and have created safe spaces for refugees and promoted the Refugees Welcome campaign. Lundberg and Strange (2016) draw attention to a conflicting dynamic where activists engage in resistance against the state's migration policing and collaborate with city-level state agencies to provide sanctuary to asylum seekers and others. In addition to Refugees Welcome efforts in Germany and central Europe, we note the proliferation of Cities of Sanctuary (United Kingdom) and Places of Sanctuary (Ireland) described as a movement that seeks to build a culture of hospitality. Since Sheffield became the first British City of Sanctuary in 2005, the United Kingdom and Ireland have witnessed over 90 City of Sanctuary initiatives.

\section{What Public Opinion Data Tell Us}

In addition to real-time reporting from the field and much public commentary via social media, one distinguishing aspect of the current "refugee crisis" is the steady release of public opinion datasets. Amnesty International's Refugees Welcome Survey, the Pew Research Center's Global Attitudes Survey, and the European Social Survey are three of the most well-cited studies conducted during this period. Although they rely on different methodologies and cover a range of countries - mostly but not exclusively overlapping states - these datasets provide a useful record of public opinion before and after the massive refugee influx began, as well as at key points in the "crisis."

The datasets are all based on structured surveys with either closed questions or a ranking system where participants select answers according to a series of responses which range from full agreement to full disagreement. The most widely publicized dataset produced by Amnesty International and the polling company GlobeScan took the form of a global survey of more than 27,000 people polled by phone and during face-to face interviews from across 27 countries between January and March 2016, well after the mass flows of refugees started reaching Europe.

The survey was global, covering Argentina, Australia, Brazil, Canada, Chile, China, France, Germany, Ghana, Greece, India, Indonesia, Jordan, Kenya, Lebanon, Mexico, Nigeria, Pakistan, Poland, Russia, South Africa, South Korea, Spain, Thailand, Turkey, the United Kingdom, and the United States. Since it included several host states in the Middle East and major destination states, this survey was of particular relevance to EU policy.

One unique feature of the survey was its focus on participants' personal commitment to support refugees. Unlike other political polling and market research, the survey used rankings to explore the degree to which respondents in the selected states were "willing" 
to let refugees live in their countries, towns, neighborhoods, and homes, among other welcome indicators, and asked the following questions, and required responses ranging from full agreement to full disagreement:

i) "People should be able to take refuge in other countries to escape from war or persecution;" and

ii) "Our government should do more to help refugees fleeing war or persecution."

According to Amnesty International, the results of the Refugees Welcome Survey showed "government refugee policies out of touch with public opinion" (Amnesty International 2016). This was most evident in EU member states, where the response to question one above was overwhelmingly in agreement and ranged from 73 percent in Poland to 94 percent in Germany as indicated in table 1 below.

\section{Table 1. Should People Be Able to Take Refuge in Other Countries to Escape from War or Persecution?}

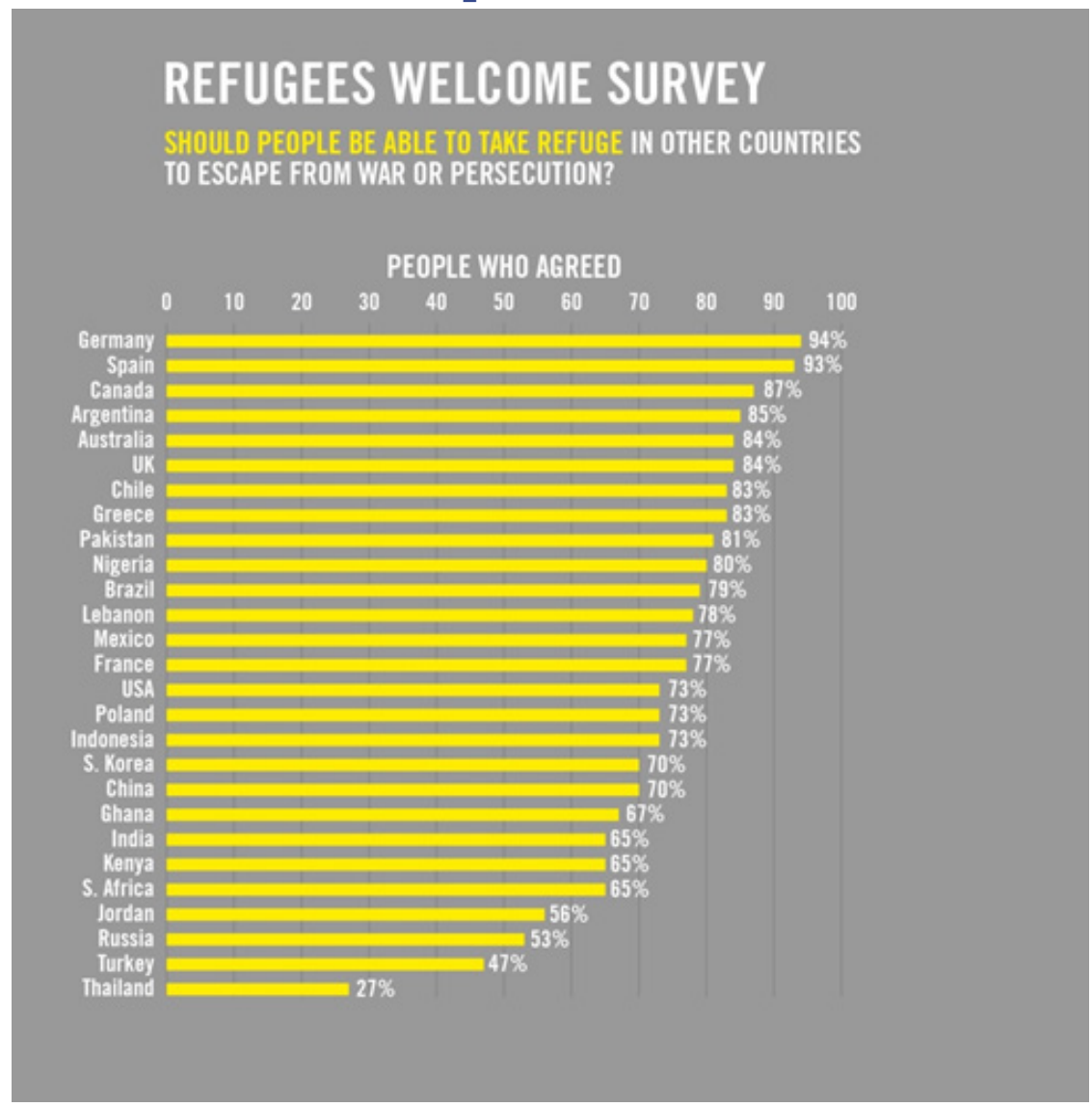

Source: Amnesty International (2016). Table courtesy of Amnesty International.

Yet, in response to question two above, about government responsibility towards refugees fleeing war or persecution, the findings present a more complex picture. In all EU member states, with the exception of Poland (43 percent), the majority of participants were in agreement, though less than reported in response to question one above. This result warrants clarification. 


\section{Table 2. Should Your Government Do More to Help Refugees Fleeing War or Persecution?}

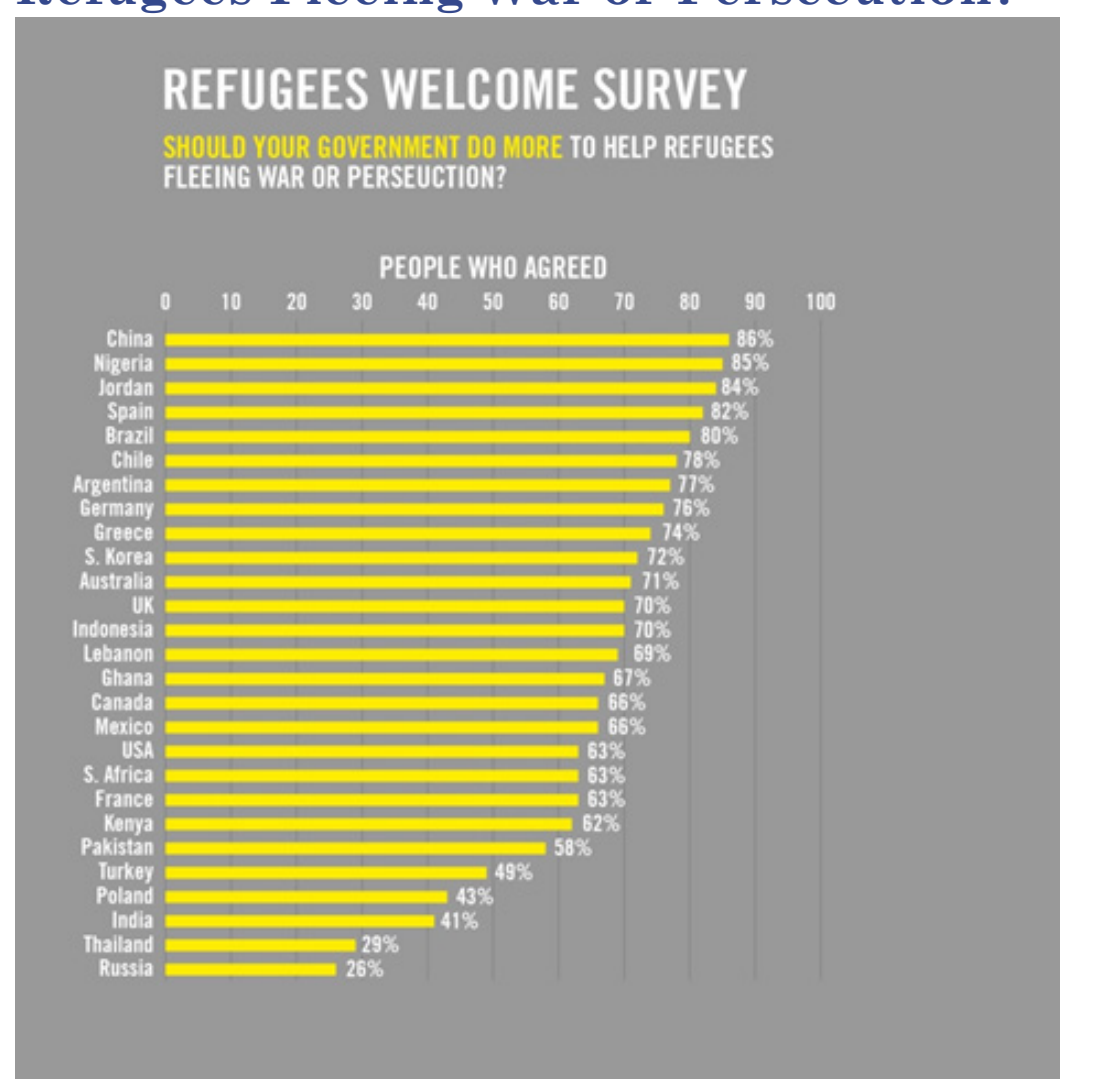

Source: Amnesty International (2016). Table courtesy of Amnesty International.

Amnesty International's survey carried a number of further limitations, not least of which was its geographical coverage. The survey's coverage of European Union member states was limited to a handful of multicultural, refugee-receiving states and countries of immigration, including France, Germany, Greece, Spain, and the United Kingdom. While the survey also featured Poland, a non-multicultural state and one at the margins of the Mediterranean "crisis," we should note that Poland has received several thousand refugees from Ukraine. Thus, although Amnesty International used a representative sample, the survey may appear biased in favor of contact with refugee and immigrant populations.

Another global instrument, Pew Research Center's Global Attitudes Survey, used similar representative sampling techniques where respondents participated in telephone and face to face surveys during fixed periods in 2016, again with a sample size of around 1,000 participants. The Pew Research Center survey also covered most of the same EU states as the Amnesty International survey, with one notable difference - Greece having been replaced by Sweden. However, unlike the Amnesty International survey, the presentation of findings indicated different patterns of dissatisfaction. Titled Euroskepticism Beyond Brexit, the Pew Research Center study drew out wider political conclusions regarding the integration of migrants, Muslims, and refugees in the European Union. A central conclusion of the study was that there was significant opposition in key European countries to greater political integration and that such opposition was linked to European policies regarding asylum and refugee management: 
"Much of the disaffection with the EU among Europeans can be attributed to Brussels' handling of the refugee issue. In every country surveyed, overwhelming majorities disapprove of how Brussels has dealt with the problem. This includes $94 \%$ of Greeks, $88 \%$ of Swedes and $77 \%$ of Italians. The strongest approval of EU management of the refugee crisis is in the Netherlands, but that backing is a tepid $31 \%$."

(Stokes 2016)

Pew Research Center's conclusion therefore targeted blame on the European Union institutions, above all the Brussels-based European Commission.

This finding begs further scrutiny. While the Pew Research Center study investigated attitudes towards the arrival of Muslim migrants in Europe, some of the questions asked by Pew Research Center required participants to identify where policy was made in order to inform their views of culpability.

While the survey raised questions about the degree to which states or the European Union as an institution might be held to account by participants, it also introduced some politically ambiguous questions. For example, we note that overwhelmingly, respondents disapproved of the way in which the European Union was "handling" the refugee crisis. Although the largest response was from refugee-hosting states such as Greece, which had already received over 800,000 migrants and refugees, and where there was broad support for solidarity and refugee sanctuary groups, we note that respondents in other countries such as Poland and the United Kingdom, which could not be described as refugee-hosting states, were similarly highly dissatisfied, possibly for different reasons.

\section{Table 3. Overwhelming Majorities in Europe Unhappy with the European Union's Handling of Refugees Do you _ of the way the European Union is dealing with the refugee issue?}

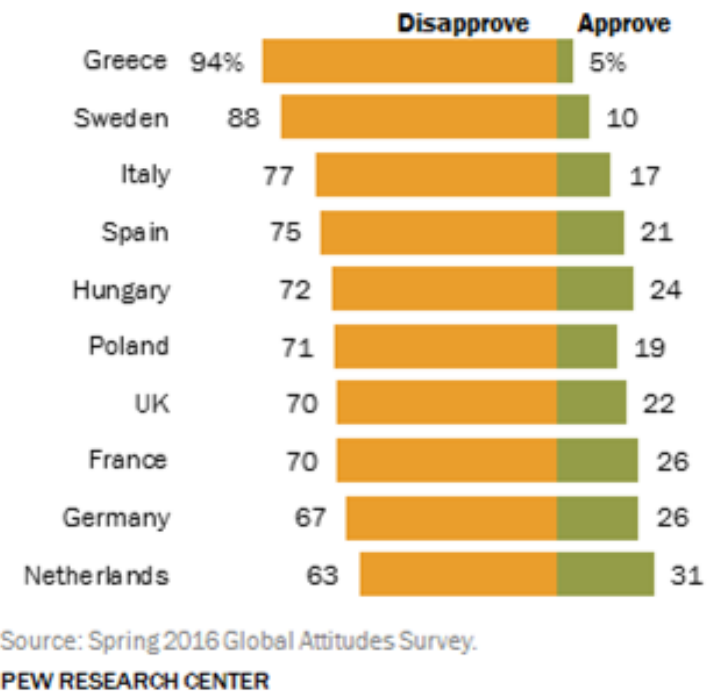

Source: Stokes (2016). Table courtesy of Pew Research Center. 
Further, and related to the above, the Pew Research Center dataset asked direct questions regarding participants' aspirations for the European Union as a global actor. In spite of much criticism reported in response to earlier questions, 55 to 90 percent of participants reported that they wanted to see the European Union taking on a greater role in global affairs. This finding, which presupposes greater unity among the European Union member states, undermines some of the wider Euroskeptic conclusions of the Pew Research Center study.

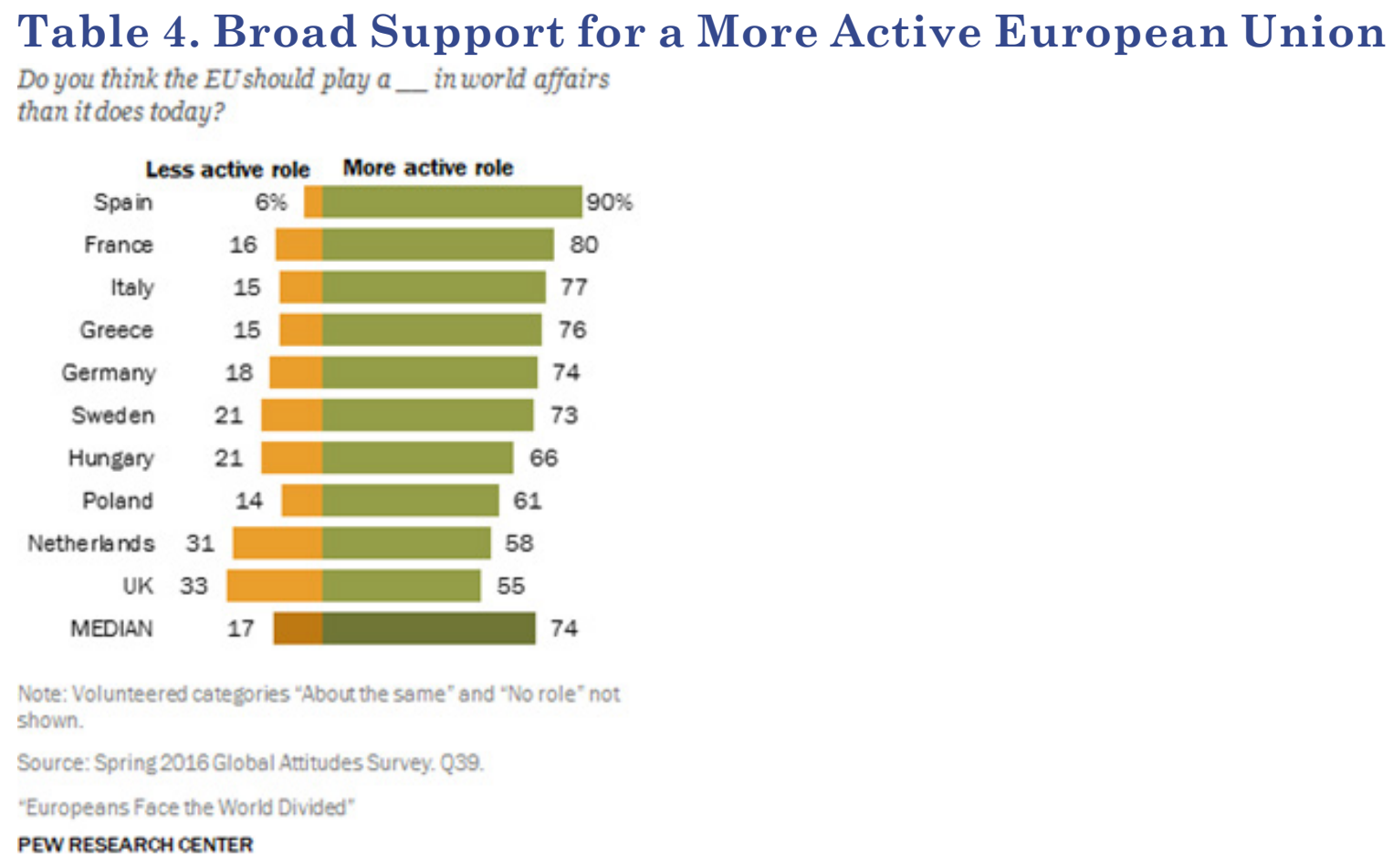

Source: Stokes (2016). Table courtesy of Pew Research Center.

Again, however, the challenge of defining the purported role of the European Union introduces many possible scenarios.

In contrast to the Amnesty International and Pew Research Center surveys, the European Social Survey (ESS) is an independent and academically driven exercise that seeks to measure the attitudes, beliefs, and behavior patterns of diverse populations in EU and non-EU states, including Russia. The ESS is conducted every two years and has been in use since 2001. It thus offers longitudinal and cross-national data. Additional themes or modules are introduced in each survey round, including a recent module on immigration in the ESS7 Round (2014-2015). Also, unlike the Amnesty International and Pew Research Center surveys, the ESS dataset includes a younger range of participants (aged 15 and over), who are residents in private households of the selected countries.

Most relevant to the European refugee crisis is the dataset from the ESS7 Round, conducted between August 2014 and December 2015, with most national responses collected in the first half of 2015. The survey included 28,221 respondents and was therefore of a similar size to the Amnesty International and Pew Research Center studies; it included more EU/ 
European Economic Area countries, in addition to Israel. In each of the surveyed states (Austria, Belgium, Switzerland, Czech Republic, Germany, Denmark, Estonia, Finland, France, Ireland, Netherlands, Norway, Poland, Sweden, and Slovenia), the sample population was 800 to 1,500 , hence again a relatively similar size to the above surveys. One question asked participants to evaluate governmental responses towards asylum.

\title{
Figure 1. Government Should Be Generous Judging Applications for Refugee Status
}

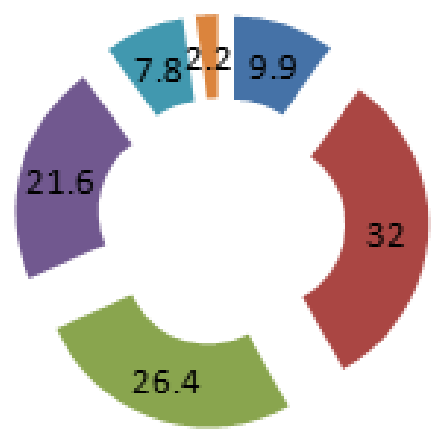

\author{
Agree strongly \\ Agree \\ Neither agree nor disagree \\ Disagree \\ Disagree strongly \\ Refused/No answer
}

Source: ESS (2016).

Other questions in the ESS7 Round probed attitudes towards the integration of migrants. Though distinct from refugees, attitudes towards migrants are a useful proxy to interpret attitudes towards refugee reception. For example, the ESS7 included a question on thirdcountry nationals, asking if participants agreed on allowing immigrants from poorer countries into Europe. The response, though qualified, illustrates a degree of openness with 54.5 percent of respondents recording that the state should allow many (14.3 percent) or some (40.2 percent) migrants to live in the selected states.

\section{Figure 2. Allow Many/Few Immigrants from Poorer Countries in Europe}
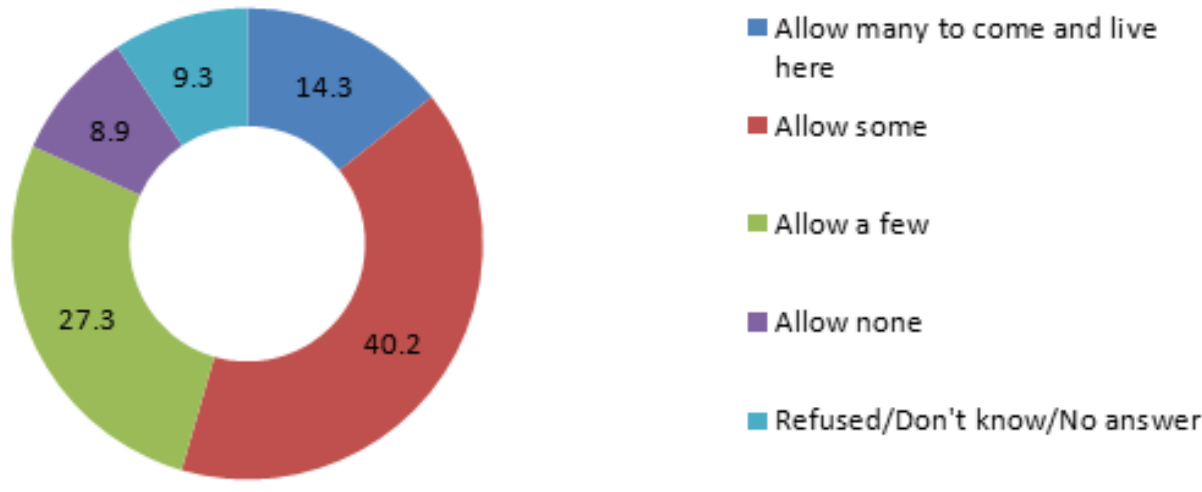

Source: ESS (2016). 
In spite of the above, further data from the ESS affirms many of the views captured in the Pew Research Center survey. With respect to migration in particular, attitudes towards "poor," nonwhite, and "non-Christian" migrants are not significantly hostile but European publics overwhelmingly prefer to admit educated populations who speak their language and are committed to "their way of life" (Stokes 2016).

In this context, the ESS recorded a slight difference in attitudes towards Muslim migrants.

\section{Figure 3. Allow Many or Few Muslims to Come and Live in Country}

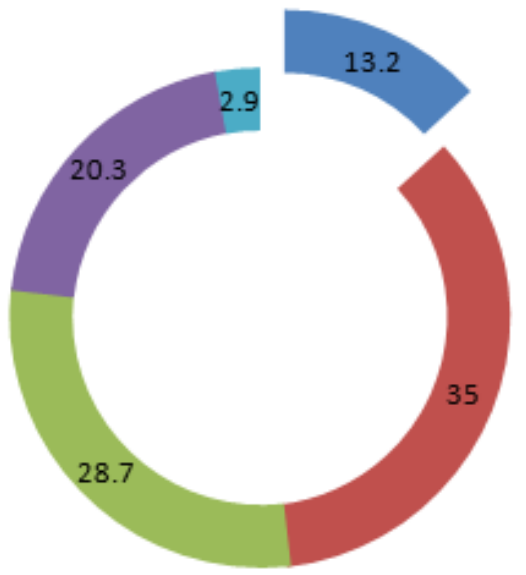

Allow many to come and live here

Allow some

Allow a few

Allow none

Refused/Don't know/No answer

Source: ESS (2016).

According to the above chart, with respect to Muslims, public attitudes towards migration and refugees do not in fact appear to be that different, suggesting that integration issues may underlie participants' responses.

\section{Analysis}

The above datasets offer a window into public attitudes towards refugees and migrants on the cusp of the current refugee crisis and during its peak. While each of above datasets illustrate important normative trends, not least because they question the principle of asylum, few commentators have sought to explain why a record of public sympathy for refugees and asylum seekers does not appear to bear any relation to the direction of public policy regarding the admission of asylum seekers and the use of humanitarian assistance. Here I offer some possible explanations.

\section{The Ambiguities of Public Opinion Surveys}

The way in which survey questions are framed does not necessarily align with rightsbased arguments for specific policy interventions. In the case of Amnesty International's survey, for example, the phrasing of some questions introduces many ambiguities that 
are exacerbated when the instrument is used for a cross-national study. We note that participants' interpretation of the nature of "help" given to refugees is understood quite differently across the European Union. This point has been repeatedly made by the UK government, which has publicized its generosity and ambitions to help refugees living in Turkey, Jordan, and Lebanon, while rejecting efforts to receive and resettle large numbers of refugees to the United Kingdom.

Moreover, public datasets assume participants have a high degree of political awareness. For example, the initial question asked by the Pew Research Center team — "Do you approve/disapprove of the way the European Union is dealing with the refugee issue?" assumes respondents can identify a distinctly EU-level response. Yet, while the European Union has both a body of law in the form of the asylum acquis and a series of polices in place that underpin the European Agenda on Migration, ${ }^{12}$ within the European Union, immigration and asylum policies remain highly nationalized. We note that commitment of member states to the asylum acquis varies, with some states having opted out of the recast directives and others interpreting their obligations less generously. Some states, like the United Kingdom, have completely opted out of common policies including the relocation scheme, a central plank to the EU-Turkey agreement. Beyond law and policy, there are also many differences in terms of state practice. Some countries like Germany and Sweden have granted large numbers of refugees status ranging from refugee status to subsidiary protection. By contrast, several central European states have hardly welcomed any people on the move. With the suspension of the Schengen Agreement, the closure of national borders remains an area of national - not EU - control. These political realities may not be understood by those sampled in the Pew survey.

\section{Cultural Antagonism}

While the above data record evidence of discriminatory views on the basis of nationality, ethnicity, and religion, this finding is magnified in political discourse on the ways in which states should respond to the needs of refugees and asylum seekers in Europe. At the heart of this argument is a claim that certain refugees - Muslims, in particular — are treated with suspicion both on account of the perceived difficulty of their integration in host states and a more generalized fear of Islamist terror. While this view is most reflected in the Pew Research Center survey, it has also been sustained and amplified in the media following the terror attacks in Paris, Brussels, Nice, Egypt, and Istanbul.

While we note that even before the death of Alan Kurdi, ${ }^{13}$ many of those sampled believed their countries should be more generous towards asylum seekers and that later surveys conducted during the summer of 2015 record a similar pattern, we also find that cultural assumptions undermine the legal definition of refugee as set out in the Refugee Convention. This is most evident in the data regarding Muslim refugees and immigrants where, in spite of the nationality and religion-blind logic of international refugee law, public attitudes are

12 Communication from the Commission to the European Parliament, the Council, the European Economic and Social Committee and the Committee of the Regions - A European Agenda on Migration, COM (2015) 240 final (May 13, 2015).

13 Alan Kurdi was a Syrian child who drowned and whose body, found face down on the beach, generated much controversy and in effect restarted the search and rescue effort. 
less sympathetic toward people from certain nationalities and religions. Similarly, in some countries, particular groups are favored - for example, displaced Ukrainians in Poland and Eritreans in Italy. Hence, we can point to important cultural and political explanations for both inhospitality and generosity towards refugees that recalls some of the geopolitical traditions of refugee policy during the Cold War.

\section{Asylum \\ Conflating Refugees and "Illegal" Immigrants to Undermine}

While refugees and economic migrants have traditionally been treated separately within Western legal traditions, popular discourse on immigration often conflates the two categories, which increasingly undermines the universal right to asylum. In some cases, this is particularly blatant. For example, during the 2016 referendum campaign on the United Kingdom's membership in the European Union, the UK Independence Party (UKIP) sought to garner support from a poster depicting a mass inflow of refugees in the Balkans, charging that migration - and in particular the right to free movement for EU nationals - had created a situation where the United Kingdom was at a breaking point, and the European Union had "failed us all." In so doing, UKIP actively sought to confuse asylum, immigration, and EU policy regarding free movement.

Such confusion, however, also works in reverse and beyond the tactics of right-wing political parties. We note that anti-immigration discourses are influencing refugee policy as more and more people question the place of refugees and asylum seekers in the cultural consensus (will they integrate) and their value or merit (potential economic contribution) to the host state. This is most evident in the differentiated levels of status afforded to new arrivals ("refugee protection" and more commonly "subsidiary protection"), often on the basis of nationality. ${ }^{14}$ Further, EU states are using profiling to reduce the numbers of asylum applicants. Although European legislation, including the Reception Conditions Directive, ${ }^{15}$ affirms international law regarding the protection of human rights of all migrants, ${ }^{16}$ in practice, the ways in which states have interpreted that requirement differs greatly. Such differentiated treatment is noted in national policy preferences. For example, Italy's positive reception of Eritreans (as opposed to other nationals), stands in marked contrast to other states, including the United Kingdom, where Eritreans were erroneously denied asylum in large numbers, only to find their claims later overturned by courts (Lyons 2016). The United Kingdom's tightening of its rules regarding the admissibility of claims from Eritreans (UK Home Office 2016), further distanced UK and Italian policies on asylum. Writing in The Guardian, Diane Taylor noted that internal UK government documents revealed that the government "downplayed the risk of human rights abuses in one of the

14 Directive 2011/95, of the European Parliament and of the Council of 13 December 2011 on standards for the qualification of third-country nationals or stateless persons as beneficiaries of international protection, for a uniform status for refugees or for persons eligible for subsidiary protection, and for the content of the protection granted, 2011 O.J. (L 337).

15 Directive 2013/33, of the European Parliament and of the Council of 26 June 2013 laying down standards for the reception of applicants for international protection, 2013 O.J. (L 180).

16 Regulation 604/13 of June 26, 2013, establishing the criteria and mechanisms for determining the Member State responsible for examining an application for international protection lodged in one of the Member States by a third-country national or a stateless person, 2013 O.J. (L 39) 1. 
world's most repressive regimes in an attempt to reduce asylum seeker numbers despite doubts from its own experts" (Taylor 2017).

At the European level, we note that the European Union's European Agenda on Migration, which includes the possibility of relocating refugees from Italy and Greece to other states, also reflects a bias in favor of certain nationalities. ${ }^{17}$ The introduction of a threshold for the European Union's relocation scheme, which is based on the average percentage of refugees admitted by nationality across the European Union and which grants the possibility of relocation only to nationals from groups with a recognition rate higher than 75 percent, further undermines the approach to refugee protection on the basis of persecution and creates new hierarchies and priorities for integration (European Commission 2016). The net effect is that thousands of others are left behind (Blitz and Kofman 2017).

\section{Dominance of Human Capital Thinking}

The above data show that the European public believes better educated migrants are easier to integrate, though arguably these views have been exaggerated in the design of policy. In practice, those arriving from low-skilled countries with limited human capital are less desirable purportedly because they will add little to Western knowledge economies. This bias contrasts with the above explicitly racist argument but nonetheless discriminates against Africans, Afghans, and other groups whose admission has been stemmed through the use of profiling and restrictions regarding relocation and resettlement schemes.

\section{Foreign Policy Justifications}

Donor preferences in favor of aid and humanitarian assistance over asylum illustrate the repoliticization of aid and a new preference for geopolitical buffering. Whereas in the Cold War era, containment complemented preferential refugee policies, now the aim is to keep refugees in the region as a means of containment in direct opposition to asylum and admission. Similarly, as the policies of donor states diverge, we note that such politicization may work in both directions where official development assistance (ODA) is used not only to fund humanitarian protection programs in frontier states but also in host countries, thus linking asylum and humanitarian spending. ${ }^{18}$ The introduction of mobility agreements in developing countries - further to the European Agenda on Migration, where states are granted aid in exchange for receiving refugees (e.g., Turkey, Ethiopia, Morocco) - explicitly reframes humanitarian policy as another facet of security policy and harkens back to a Cold War logic. As such, this approach de-emphasizes the rightsbased logic underlying refugee protection and humanitarian goals, and brings donor states into contention with international law, as for example, regarding the EU-Turkey deal and recent Italy-Libya readmission initiatives.

17 Communication from the Commission to the European Parliament, the Council, the European Economic and Social Committee and the Committee of the Regions - A European Agenda on Migration, COM (2015) 240 final (May 13, 2015).

18 Organisation for Economic Co-operation and Development's Development Assistance Committee data, from 2010 to 2015, records that ODA spending for in-donor refugee costs rose from $\$ 3.4$ billion to $\$ 12$ billion. The share of total net ODA spent on refugee assistance rose from 2.7 percent in 2010 to 9.1 percent in 2015 (OECD DAC 2016). 


\section{Journal on Migration and Human Security}

\section{Normalizing Repression through Border Controls}

The extra-territorialization of border controls, as demonstrated by the use of offshore processing by Australia (e.g., Nauru, Manus Island, Papua New Guinea) and the deployment of asylum and immigration officers in third countries, has enabled states to extend their claims to jurisdiction and hence also management of asylum. The use of this type of agreement, in addition to the European Migration Agenda and mobility agreements described above, in turn informs political discourse and undermines alternatives to refugee protection, for example, the possibility of safe passage and creation of legal routes to asylum. The net effect has been the creation of a new discourse that is antagonistic towards the idea of refugee protection.

\section{Conclusion}

The current refugee crisis presents a distinct vantage point from which one may interpret the evolution of humanitarian and asylum policies. Above I suggest that this episode calls attention to cracks in the post-Cold War approach towards humanitarian policy and attempted harmonization of European policies regarding asylum. Rather, as in the Cold War era, we are witnessing the fusing of security and humanitarian policies and the introduction of increasingly restrictive practices on asylum, in spite of evidence of significant public support.

The above datasets record overwhelming support for the principle of asylum which are underlined by calls for greater generosity towards refugees and more active intervention by the European Union. However, support for the admission of refugees is not unqualified and most states and European populations prefer skilled populations that can be easily assimilated. Ease of assimilation on the basis of education and skills appears to be one of the most significant markers. Though the European public is on record as being less generous towards Muslims, neither religion, nor country of origin, appear particularly significant. This finding from the above data suggests that in spite of public sympathy, European governments appear out of sync by pressing ahead with policies that run counter to public demands.

Noting potential ambiguities in the above datasets, this paper offers five further explanations for the disjunction between public opinion and current policy on refugees, asylum seekers, and humanitarian assistance. It claims that reported public concerns regarding cultural antagonism and the integration of asylum seekers have been greatly magnified and identifies a Cold War-style logic where aid and humanitarian assistance are principally determined on the basis of foreign policy interests, though the containment of refugee and asylum-seeking populations in the region and the use of humanitarian assistance to create buffer zones illustrates notable discontinuities with past policies. In spite of much public sympathy, the above developments in humanitarian and refugee policies have culminated in a discourse that is undermining the universal right to seek asylum.

\section{Recommendations}

Public opinion data record considerable evidence of sympathy and generosity which is

not reflected in current European policies. In order to press for greater refugee protection, 


\section{Another Story: What Public Opinion Data Tell Us}

the premise of coupling asylum and humanitarian policies with security policies must be challenged. This can be done best by:

- Refining public opinion surveys so that questions are closely defined to avoid ambiguity and cross-cultural misunderstanding.

- Challenging the discourse on exclusion and securitization by working with human rights actors, the UNHCR, and its partners on dedicated media campaigns which affirm public support and identify how restrictive asylum policies fail to advance foreign interests.

- Challenging efforts to normalize illegal and inhumane practices, e.g., detention, offshore processing, and the separation of families through the courts; these decisions must be widely disseminated as part of a coordinated information campaign to present a counter moral argument.

- Evidencing persecution by sharing information with the press and government agencies on the nature of claims by those currently considered ineligible for refugee protection as part of a wider campaign of information and inclusion.

- Engaging with minority, and in particular Muslim, communities to redress public concerns regarding the possibility of cultural integration in the host country.

- Clarifying the rights of refugees and migrants in line with the UNHCR and IOM guidelines and European and national law in order to hold governments to account and to ensure that all — irrespective of their skills, status, nationality, or religion — are given the opportunity to seek asylum.

\section{REFERENCES}

Amnesty International. 2016. "Refugees Welcome Index Shows Government Refugee Policies Out of Touch with Public Opinion." https://www.amnesty.org/en/latest/ news/2016/05/refugees-welcome-index-shows-government-refugee-policies-outof-touch/.

Blitz, Brad, and Eleonore Kofman. 2017. "Refugees Count." The Economist, March 30. http://www.economist.com/news/letters/21719756-scoxit-domino-theoryquantum-physics-refugees-inequality-apostrophes-letters.

Bocco, Riccardo, ed. 2009. "UNRWA and the Palestinian Refugees: A History within History." Refugee Survey Quarterly 28(2-3): 229-52. https://doi.org/10.1093/rsq/ hdq001.

Bon Tempo, Carl J. 2008. Americans at the Gate: The United States and Refugees During the Cold War. Princeton: Princeton University Press.

Brunsden, Jim. 2017. "Europe Refugee Policy is 'Trojan Horse of Terrorism,' says Orban." Financial Times, March 30. https:/www.ft.com/content/538b2a0a-154e-11e780f4-13e067d5072c. 
Carrera, Sergio, and Raül Hernández i Sagrera. 2009. "The Externalisation of the EU's Labour Immigration Policy: Towards Mobility or Insecurity Partnerships?” CEPS Working Document No. 321. Brussels: Centre for European Policy Studies. http:// aei.pitt.edu/14589/1/WD321_Carrera_and_Sagrera_e-version_final.pdf.

Council of the European Union. 2002. "Presidency Conclusions - Seville, 21 and 22 June 2002.” Brussels: Council of the European Union. http://www.consilium.europa.eu/ en/workarea/downloadAsset.aspx?id=40802198177.

—. 2016. "EU-Turkey statement, 18 March 2016." Brussels: Council of the European Union. http://www.consilium.europa.eu/en/press/press-releases/2016/03/18-euturkey-statement/.

Duffield, Mark. 2001. "Governing the Borderlands: Decoding the Power of Aid." Disasters 25(4): 308-20. https://doi.org/10.1111/1467-7717.00180.

ESS (European Social Survey). 2016. "ESS7 Edition 2.1." London: ESS. http://www. europeansocialsurvey.org/data/round-index.html.

European Commission. 2014. The Cotonou Agreement and Multiannual Financial Framework 2014-20. Luxembourg: European Commission. http://www.europarl. europa.eu/intcoop/acp/03_01/pdf/mn3012634_en.pdf.

- 2016. Eighth report on relocation and resettlement. Brussels: European Commission. https://ec.europa.eu/home-affairs/sites/homeaffairs/files/whatwe-do/policies/european-agenda-migration/proposal-implementation-package/ docs/20161208/eighth_report_on_relocation_and_resettlement_en.pdf.

—. 2017. "Syria Crisis." ECHO factsheet, March. https://ec.europa.eu/echo/files/aid/ countries/factsheets/syria_en.pdf.

European Parliament. 1999. "Tampere European Council 15 and 16 October 1999 Presidency Conclusions." Tampere, Finland: European Parliament. http://www. europarl.europa.eu/summits/tam_en.htm.

Garcia, Marcia Christina. 1996. Havana USA: Cuban Exiles and Cuban Americans in South Florida, 1959-1994. Berkeley, CA: University of California Press.

The Guardian. 1997. "Robin Cook's Speech on the Government's Ethical Foreign Policy." The Guardian, May 12. https://www.theguardian.com/world/1997/may/12/ indonesia.ethicalforeignpolicy.

Keating, Joshua. 2015. "Here's Why Eastern Europe Is So Much More Antagonistic to Syria's Refugees than Western Europe." Slate, September 14. http://www.slate. $\mathrm{com} / \mathrm{blogs} / \mathrm{the}$ slatest $/ 2015 / 09 / 14 /$ here_s_why_eastern_europe_is_so_much_ more_antagonistic_to_syria_s_refugees.html.

Loescher, Gil, and John A. Scanlan. 1986. Calculated Kindness: Refugees and America's Half-Open Door: 1945-Present. New York: Free Press. 
Lundberg, Anna, and Michael Strange. 2016. "Who provides the conditions for human life? Sanctuary movements in Sweden as both contesting and working with state agencies." Politics. https://doi.org/10.1177/0263395716661343.

Lyons, Kate. 2016. "Hundreds of Eritreans' Asylum Applications Still 'Incorrectly Refused." The Guardian, July 28. https://www.theguardian.com/uk-news/2016/ jul/28/hundreds-of-eritrea-asylum-applications-still-incorrectly-refused.

Macrae, Joanna, and Nicholas Leader. 2000. "Shifting sands: The search for 'coherence' between political and humanitarian responses to complex emergencies." Humanitarian Policy Group Report 8. London: ODI (Overseas Development Institute). https://www.odi.org/sites/odi.org.uk/files/odi-assets/publicationsopinion-files/299.pdf.

Macrae, Joanna, Emery Brusset, and Christine Tiberghien. 2002. "Coherence or Cooption? Europe and the New Humanitarianism.” London: ODI. https://www.odi.org/sites/ odi.org.uk/files/odi-assets/publications-opinion-files/3411.pdf.

MSF (Médecins Sans Frontières). 2016. "MSF to No Longer Take Funds From EU Member States and Institutions." London: MSF. https://www.msf.org.uk/article/msf-nolonger-take-funds-eu-member-states-and-institutions.

Newland, Kathleen. 1995. U.S. Refugee Policy: Dilemmas and Directions. Washington, DC: Carnegie Endowment for International Peace.

Nye, Joseph S. 1999. "Redefining the National Interest." Foreign Affairs 78(4). https://doi. org/10.2307/20049361.

Provost, Claire. 2006. The Privatisation of UKaid: How Adam Smith International is profiting from the aid budget. London: Global Justice Now. https://www.globaljustice.org. $\mathrm{uk} /$ sites/default/files/files/resources/the_privatisation_of_uk_aid.pdf.

Scott, Colin, and Ian Bannon. 2003. “Mind the Gap': The World Bank, Humanitarian Action and Development - A Personal Account." Social Development Department Dissemination Notes No. 10. Washington, DC: World Bank. https:// openknowledge.worldbank.org/handle/10986/11306.

Spindler, and Jonathan Clayton. 2016. "UNHCR Expresses Concern over EU-Turkey Plan.” Geneva: UNHCR. http://www.unhcr.org/uk/news/latest/2016/3/56dee1546/ unhcr-expresses-concern-eu-turkey-plan.html

Stokes, Bruce. 2016. Euroskepticism Beyond Brexit: Significant opposition in key European countries to an ever closer EU. Washington, DC: Pew Research Center. http:// www.pewglobal.org/files/2016/06/Pew-Research-Center-Brexit-Report-FINALJune-7-2016.pdf.

Takkenberg, Lex, ed. 2009. "UNRWA and the Palestinian Refugees After Sixty Years: Some Reflections.” Refugee Survey Quarterly 28(2-3): 253-59. https://doi.org/10.1093/ rsq/hdp050. 


\section{Journal on Migration and Human Security}

Taylor, Diane. 2017. "Home Office Eritrea Guidance Softened to Reduce Asylum Seeker Numbers." The Guardian, January 22. https://www.theguardian.com/ uk-news/2017/jan/22/home-office-eritrea-guidance-softened-to-reduce-asylumseeker-numbers.

Truman, Harry S. 1947. "Recommendation for Assistance to Greece and Turkey: Address of the President of the United States Delivered Before a Joint Session of the Senate and the House of Representatives, Recommending Assistance to Greece and Turkey." Speech, Washington, DC, March 12. https:/www.ourdocuments.gov/ doc.php?doc $=81 \#$.

UK Home Office. 2016. “Country Policy and Information Note: Eritrea: National Service and Illegal Exit." London: UK Home Office. https://www.gov.uk/government/ uploads/system/uploads/attachment_data/file/565635/CPIN-Eritrea-NS-andIllegal-Exit-v4-October-2016.pdf.

UK House of Commons. 2017a. "Changes in US Immigration Policy: 30 January 2017." House of Commons debate, London, January 30. https://hansard.parliament.uk/ commons/2017-01-30/debates/448738C3-927F-481B-8340-809810F30595/ ChangesInUSImmigrationPolicy.

—. 2017b. "Unaccompanied Child Refugees: 09 February 2017." House of Commons debate, London, February 9. https://hansard.parliament.uk/ commons/2017-02-09/debates/441DB6F3-2F20-4A12-A13C-9CB86838707E/ UnaccompaniedChildRefugees.

Zucker, Naomi Flink, and Norman L. Zucker. 1995. "US Admission Policies Towards Cuban and Haitian Migrants." In The Cambridge Survey of World Migration, edited by Robin Cohen, 447-51. Cambridge: Cambridge University Press. 